\title{
In/ter/dependence: An afterword
}

\author{
Jean and John Comaroff
}

\begin{abstract}
Our closing reflection on the collection of articles in this issue argues that the modernist bourgeois figure of the autonomous individual, founded from the first on a Promethean fiction, has long hidden the sorts of dependencies, interdependencies, and intradependencies intrinsic to social life everywhere. This is all the more so in the twenty-first century, under conditions in which the relations between capital and labor, patterns of sociality and social reproduction, and Euromodernity itself are undergoing wide-ranging changes, changes that are deepening the tensile coexistence of human autonomy and entanglement.
\end{abstract}

Keywords: dependence, gender, interdependence, kinship, labor, social reproduction

In one form or another, the concept of dependence has, from the first, been foundational to modern understandings of humanity, society, and economy. For liberal theorists, individual freedom stemmed from a natural right to property that owed "nothing to society"; those without proprietorship of person and possessions were reduced to a dehumanized "dependance on the wills of others" (Macpherson 1962: 3). In this formulation, dependence connotes incompleteness, indigence, disenfranchisement. The Great Confinement of seventeenth-century France, Foucault argues, applied state discipline to those who failed to exercise industrious self-production. For more collectivist thinkers, it was precisely the multivalent interdependence of humankind as species that ensured its innately social character. And its social survival.

In fact, it was the incompleteness of individuals and groups as self-propagating entities that, for Durkheim, fostered the moral cohesion of society. And, rather than becoming more selfdetermining with industrialization and its complex division of labor, humans became ever more intricately interdependent, even if more indirectly so. Thus Durkheim's insistence that the "cult of individualism" was a modernist myth, a Promethean fiction sanctified by the artifacts of liberal world-making: personal rights, contracts, the law of supply and demand. Hegel took the implications of dependence in a dialectical direction: it was the reciprocal, if unequal, dependence of master and slave that gave rise to intersubjective consciousness. Famously, Marx reformulated this dynamic as the structural conflict between classes, itself an historic interplay between two orders of dependence: of workers on wage labor, and of capital on the value extracted from their toil. Just as the self-determination of bourgeois individualism disavows its entangle- 
ment in a web of social relations, so the ideological erasure of socially embedded productivity has its parallel in the fetishism of commodities under capitalism: a process by which objects of human manufacture take on the appearance of autonomous things with intrinsic value and an independent life.

In its conventional liberal usage, then, dependence implies both moral and material insufficiency, immaturity, and reliance on others. It draws on the telos of nineteenth-century evolutionary biology that used the logic of "development" and "progress" to splinter humankind into the more or less civilized, the more or less modern, rational, self-possessed, thus to order hierarchies of power and value. The social and spatial gestalt of Western industrial society, with its nesting order of interdependent yet unequal domains-female:male, kinship:market, family: state, colony:metropole, in each case the former dependent, the latter independent-idealized this political economy. Critics have long contested its core ideological assumptions, not least the very way in which dependency has been defined. Not only were capital and labor reciprocally dependent, but female domestic work, along with the work of people of color and other discounted producers, was integral to the male-centric accumulation of wealth. Of course, the effort to free itself entirely from a dependency on human labor is arguably a leitmotif of the history of capitalism, this by rendering workers ever more redundant, absent, abject (Comaroff and Comaroff 2020). What is more, we are now living through times in which wage work is widely held to be even less central than before to the production of wealth, when mechanization and financialization have led to talk of "the end of labor," when rising informal economies are becoming the new normal even in the capitalist heartlands; times, more generally, in which received, modernist articulations of economy, polity, and society are being radically reconfigured. In the process, new forms of inter/dependency are emerging, and lines are being redrawn between autonomy and reliance, debt and solvency, production and circulation.
Some, like James Ferguson (2015: 100), have argued that dependency itself requires to be rethought, more appropriately, as a site of "distributive labor," attachment, and moral obligation.

Hence the renewed preoccupation in recent decades with dependence, to which this fine clutch of articles speaks. That preoccupation is a symptom of a global shift in long-standing liberal configurations of gender, labor, and social reproduction. Thus, for example, Ståle Wigwho, like others, argues that the self-made, autonomous person is an illusion-explores the performance of imagined individuality among Cuban market traders, men and women each deploying different techniques of the self, each calling out or hiding the moral and material dependencies that make the illusion real; the point, patently, lies in the fact that the practical construction of personhood is always an act of profound social entailment, of existential interdependence. This last point is extended very cogently by Holly Wardlow, who, in looking into the lives of women with HIV in Papua New Guinea, shows that these "dead" individuals-dead because they are only alive due to ARVs-are held accountable for two things at once: excessive independence, manifest in their uncontrolled sex, and excessive dependence, in that they require care, as do their own dependents, to survive. The women themselves protest this. What local discourse does not allow is that this is a case, at once, of interdependence and intradependence; that is, dependence inside dependencies, creating a web of relations of mutuality among those radically individuated by their physical situation. Dependence, intradependence, and interdependence are three interwoven, locally agonistic faces of sociality here, as everywhere.

If anything brings the question of in/ter/ dependence to the fore at this moment of radical reconfiguration, it is the relationship between citizen and state, which Katherine Smith explores in the context of an English public housing estate. She argues that dependence on welfare, itself deeply moralized, permits nothing but bare survival in place, without any vision of a tomor- 
row; even more so now under conditions of extreme austerity. What comes starkly to the fore, here, is the impossibility of social reproduction. But when the dependent has dependents, future making is essential: it inheres in the very fact of parenthood. In sum, it is not only the dialectics of dependence in the here and now that are in question. It is also their necessary deployment in the forward movement of time.

Kinship and domesticity-real, fictive, or idiomatic-is a critical site in which those dialectics play out. Lotte Danielsen, contesting James Ferguson's (2015) claim that South Africans seek out hierarchical dependencies, demonstrates that black domestic workers employed by white families clearly would prefer to avoid relations of subordination. But they often cannot, given the difficulties of garnering income by other, less subservient means. Domestic labor is especially prone to degrading, unregulated toil: the afterlife of colonial norms tend to cast female domestic workers most readily as daughterly dependents, that is, in the paternalist idiom of kinship, pretending to mutual responsibility, affect, gift exchange. Black men, disparagingly referred to as "boys," are kept away from the inner sanctum of the family home, being made to labor "outside." Both women and men resent their subordination. Yet they are also alive to possibilities that lie in the ambiguous coexistence of kinship and wage labor. Women in particular use faux intimacy to press obligations, striving to turn inter/ dependence into an economic survival strategy, even a pathway to a life beyond subordination for themselves and their children.

These observations come together, more or less directly, in Susana Narotzky's article on intergenerational relations. She, too, plants her gaze firmly on intimate kinship and domestic relations. In Spain the creation of greater familial and domestic dependency has resulted from economic liberalization, the shrinking of the labor market, state retraction, and austerity. Thus are micro-sociology and macro-political economy, state and citizen, family and society, waged and non-waged work entailed in one another. And entailed in a structural moment that seems unsustainable, one in which younger people, whose aspirations to independence have been put on long hold, are imbricated in intergenerational relations that conduce to deep ambivalence: to a paradox of autonomy and dependency, mutual care and resentment. What is more, dependency, here as everywhere, takes multiple forms, including ones that feed increasingly unrealistic models of entrepreneurial individualism. The more general implication? That those domestic (inter, intra) dependencies subsidize and devalue wage employment, relieving capital and the state of the costs of social reproduction. In the upshot, human life becomes enmeshed in a tight weave of contradictions, a counterpoint of social and affective relations among persons-at once individuated and socially embraced-way too complex to be reduced to terms like dependency or autonomy.

This takes us back to our general point. In the long history of Euromodernity, capital has sought perennially to undermine labor, keeping it dependent (or making it redundant) while celebrating and theologizing the figure of the autonomous, self-possessed individual: an adult white male situated in a domestic family whose unpaid female toil sustained the very possibility of social reproduction. In the process, the rank dependency of capital, on both the paid wage labor it constantly devalued and the unpaid domestic labor that ensured its reproduction, was carefully hidden-making it, capital, appear to be the independent, driving force of history. With the radical reconfiguration of economy, society, and the state, that delicate balance, hidden in plain sight, has become unfixed, rendering the dialectic of dependence and autonomy-that is, of the dependence of independence on interdependence-starkly clear. And existentially, socially, and theoretically problematic, a deep challenge for the social sciences, and human life everywhere, to confront.

Jean Comaroff is the Alfred North Whitehead Professor of African and African American Studies and of Anthropology at Harvard Uni- 
versity, USA, where she is also an Oppenheimer Fellow in African Studies. Author of Body of Power, Spirit of Resistance (1985), her books, co-authored and co-edited with John Comaroff, include Of Revelation and Revolution (2 vols.), Ethnography and the Historical Imagination, Law and Disorder in the Postcolony, Ethnicity, Inc., Theory from the South, or How EuroAmerica is Evolving toward Africa, The Truth about Crime: Sovereignty, Knowledge, Social Order, The Politics of Custom: Chiefship, Capital, and the State in Contemporary Africa, and (with G.P. Meiu) Ethnicity, Commodity, In/Corporation. Email: jeancomaroff@fas.harvard.edu

John Comaroff is Hugh K. Foster Professor of African and African American Studies and of Anthropology at Harvard University, where he is also an Oppenheimer Fellow in African Studies. Co-author with Simon Roberts of Rules and Processes: The Cultural Logic of Dispute in an African Context (1981), his books, co-authored and co-edited with Jean Comaroff, include Of Revelation and Revolution (2 vols.), Ethnography and the Historical Imagination, Law and Disorder in the Postcolony, Ethnicity, Inc., Theory from the South: or, How Euro-America Is Evolving toward Africa, The Truth about Crime, The Politics of Custom: Chiefship, Capital, and the State in Contemporary Africa, and (with G.P. Meiu) Ethnicity, Commodity, In/Corporation.

Email: jcomaroff@fas.harvard.edu

\section{References}

Comaroff, Jean, and John Comaroff. 2020. "After labor." Critical Historical Studies 7(1): 87-112.

Ferguson, James. 2015. Give a man a fish: Reflections on the new politics of distribution. Durham, NC: Duke University Press.

Macpherson, Crawford Brough. 1962. The political theory of possessive individualism: Hobbes to Locke. Oxford: Clarendon Press. 